Article

\title{
Anti-Mycobacterium tuberculosis Activity of Esters of Quinoxaline 1,4-Di-N-Oxide
}

\author{
Isidro Palos ${ }^{1}$ (D), Julieta Luna-Herrera ${ }^{2}$ (D), Edgar E. Lara-Ramírez ${ }^{3}$, Alejandra Loera-Piedra ${ }^{2}$, \\ Emanuel Fernández-Ramírez ${ }^{2}$, Ma. Guadalupe Aguilera-Arreola ${ }^{4}$, Alma D. Paz-González ${ }^{5}$, \\ Antonio Monge ${ }^{6}$, Baojie Wan ${ }^{7}$, Scott Franzblau ${ }^{7}$ and Gildardo Rivera ${ }^{5, *}$ \\ 1 Unidad Académica Multidisciplinaria Reynosa-Rodhe, Universidad Autónoma de Tamaulipas, \\ Carr. Reynosa-San Fernando, s/n, Reynosa 88779, Mexico; isi_palos@hotmail.com \\ 2 Departamento de Inmunología, Escuela Nacional de Ciencias Biológicas, Instituto Politécnico Nacional, \\ Ciudad de México 11340, Mexico; julietalunah@hotmail.com (J.L.-H.); ide_shadows@hotmail.com (A.L.-P.); \\ g.u.ero69@hotmail.com (E.F.-R.) \\ 3 Unidad de Investigación Biomédica de Zacatecas, Instituto Mexicano del Seguro Social (IMSS), \\ Alameda Trinidad García de la Cadena, s/n, Zacatecas 98000, Mexico; elarar0700@hotmail.com \\ 4 Departamento de Microbiología, Escuela Nacional de Ciencias Biológicas, Instituto Politécnico Nacional, \\ Ciudad de México 11340, Mexico; lupita_aguilera@hotmail.com \\ 5 Laboratorio de Biotecnología Farmacéutica, Centro de Biotecnología Genómica, Instituto Politécnico Nacional, \\ Boulevard del Maestro, s/n, Esq. Elías Piña, Reynosa 88710, Mexico; apazg@ipn.mx \\ 6 Unidad de Investigación y Desarrollo de Medicamentos, Centro de Investigación en Farmacobiología \\ Aplicada (CIFA), Universidad de Navarra, C/Irunlarrea s/n, 31080 Pamplona, Spain; amonge@unav.es \\ 7 Institute for Tuberculosis Research, College of Pharmacy, University of Illinois at Chicago, 833 S. Wood St., \\ Chicago, IL 60612, USA; baojie@uic.edu (B.W.); sgf@uic.edu (S.F.) \\ * Correspondence: gildardors@hotmail.com; Tel.: +52-899-924-3627; Fax: +52-899-924-3628
}

Received: 15 May 2018; Accepted: 13 June 2018; Published: 15 June 2018

\begin{abstract}
Tuberculosis continues to be a public health problem in the world, and drug resistance has been a major obstacle in its treatment. Quinoxaline 1,4-di- $N$-oxide has been proposed as a scaffold to design new drugs to combat this disease. To examine the efficacy of this compound, this study evaluates methyl, ethyl, isopropyl, and n-propyl esters of quinoxaline 1,4-di- $\mathrm{N}$-oxide derivatives in vitro against Mycobacterium tuberculosis (pansusceptible and monoresistant strains). Additionally, the inhibitory effect of esters of quinoxaline 1,4-di- $N$-oxide on $M$. tuberculosis gyrase supercoiling was examined, and a stability analysis by ultra performance liquid chromatography-tandem mass spectrometry (UPLC-MS) was also carried out. Results showed that eight compounds (T-007, T-018, T-011, T-069, T-070, T-072, T-085 and T-088) had an activity similar to that of the reference drug isoniazid (minimum inhibitory concentration $(\mathrm{MIC})=0.12 \mu \mathrm{g} / \mathrm{mL}$ ) with an effect on nonreplicative cells and drug monoresistant strains. Structural activity relationship analysis showed that the steric effect of an ester group at 7-position is key to enhancing its biological effects. Additionally, T-069 showed a high stability after $24 \mathrm{~h}$ in human plasma at $37^{\circ} \mathrm{C}$.
\end{abstract}

Keywords: esters; quinoxaline 1,4-di-N-oxide; Mycobacterium tuberculosis; DNA gyrase; drug resistance

\section{Introduction}

According to the World Health Organization (WHO), tuberculosis (TB) continues to be one of the leading infectious diseases in the world [1]. First- and second-line drugs are available for the treatment of the disease. However, the present therapy has been ineffective due to its long duration, as well as the emergence of resistance to these drugs [2]. In view of the significance of TB as an infectious disease 
and the increasing incidence of resistant strains, the development of new drugs for the treatment of TB is urgently needed.

Quinoxalines are a series of compounds with diverse biological activities that have what is considered a privileged structure [3]. Carta and collaborators proposed quinoxaline 1,4-di- $\mathrm{N}$-oxide as a scaffold for the development of new antituberculosis drugs [4]. In particular, Monge's research group reported a series of quinoxaline 1,4-di- $\mathrm{N}$-oxide derivatives with excellent antituberculosis activity in resistant and multiresistant strains of Mycobacterium tuberculosis (M. tuberculosis) as well as nonreplicative cells in in vitro and in vivo models [5,6]. Interestingly, the change of the 2-carbonitrile by the 2-carboxylate group increased the solubility of the compounds and their biological activity [7]. Analysis of the structure-activity relationship (SAR) of quinoxaline 1,4-di- $\mathrm{N}$-oxide derivatives clearly indicates that at 2- and 7-position on the quinoxaline ring, carboxylate and electro-attracting groups (halogen atoms), respectively, are preferred. Also, a methyl group at 3-position is a good option for antitubercular activity [8]. Additionally, quinoxaline 1,4-di- $\mathrm{N}$-oxide derivatives have an effect against nonreplicating persistent (NRP) bacteria [9]. A study by Pan et al. showed that quinoxaline 1,4-di- $N$-oxide derivatives have a potent antitubercular activity (minimum inhibitory concentration (MIC) $<0.4 \mu \mathrm{g} / \mathrm{mL}$ ) and null cytotoxicity on Vero cell lines [10]. However, in general, quinoxaline 1,4-di- $N$-oxide derivatives show solubility problems. In line with the development of new, more effective, and less toxic antituberculosis agents, our research group in this work propose the incorporation of an ester group (methyl, ethyl, isopropyl, and n-propyl) at 7-position on the quinoxaline 1,4-di- $N$-oxide ring as a strategy to enhance the solubility and biological activity of these derivatives.

Additionally, it has been reported that quinoxaline 1,4-di- $N$-oxide derivatives have a novel mechanism of action unrelated to current antitubercular drugs [11]. A proposed mechanism of action indicates that antimicrobial quinoxalines prevent the synthesis of RNA by binding to the CpG site on DNA [12]. However, a study examining compounds derived from 2,3-dichloroquinoxaline has indicated that they may be inhibitors of the enzyme chorismate mutase [13]. In addition to the mechanisms of action described, Radwan et al. have determined that quinoxaline 1,4-dioxide derivatives are capable of interacting on the active site of DNA gyrase of $M$. tuberculosis [14]. Therefore, in this study, a inhibitory analysis of esters of quinoxaline 1,4-di- $\mathrm{N}$-oxide derivatives on $M$. tuberculosis gyrase supercoiling was done to understand their potential mechanism of action. Finally, a chromatographic analysis to test plasma stability of esters of quinoxaline 1,4-d- $\mathrm{N}$-oxide was also carried out.

\section{Results and Discussion}

\subsection{Biological Activity}

A common procedure to obtain quinoxaline 1,4-di- $N$-oxide derivatives is the use of benzofuroxane $\mathrm{N}$-oxide as a principal reagent [15]. Additionally, benzofuroxane $\mathrm{N}$-oxide is a heterocyclic compound with antitubercular activity [16]. Therefore, as a first step, benzofuroxane- $N$-oxide derivatives were used to obtain esters of quinoxaline 1,4-di- $\mathrm{N}$-oxide, which were also evaluated in vitro on M. tuberculosis strain H37Rv and the NRP strain. Results are shown in Table 1. SAR analysis showed that the compound T-046 with a hydrogen atom at $\mathrm{R}_{1}$ position on the benzofuroxane $N$-oxide ring had a lower MIC value $(58.5 \mu \mathrm{g} / \mathrm{mL})$. However, when a carboxylate group was added at $\mathrm{R}_{1}$-position, the biological activity was enhanced sevenfold (compound T-014, MIC $=7.6 \mu \mathrm{g} / \mathrm{mL}$ ). This effect increased when a carboxylate group with an aliphatic linear substituent was incorporated at the same position on the benzofuroxane $N$-oxide ring (T-074, MIC $=0.87 \mu \mathrm{g} / \mathrm{mL}$ ). These results confirm that the steric effect at $\mathrm{R}_{1}$-position modulates anti-M. tuberculosis activity. Additionally, a second substitution at $R_{2}$-position drastically reduced the activity (T-036, MIC $>100 \mu \mathrm{g} / \mathrm{mL}$ ). These results show that the benzofuroxane-5-carboxylate $\mathrm{N}$-oxide ring is a good scaffold to develop new antitubercular agents. 
Table 1. Biological activity of benzofuroxane $N$-oxide derivatives using the microplate Alamar blue assay (MABA) against Mycobacterium tuberculosis strain H37Rv and the low oxygen recovery assay (LORA) against the nonreplicating persistent strain.

\begin{tabular}{|c|c|c|c|c|}
\hline Code & $\mathbf{R}_{\mathbf{1}}$ & $\mathbf{R}_{2}$ & MABA MIC $(\mu \mathrm{g} / \mathrm{mL})$ & LORA MIC $(\mu \mathrm{g} / \mathrm{mL})$ \\
\hline T-014 & $\mathrm{CH}_{3} \mathrm{OOC}$ & $\mathrm{H}$ & 7.6 & 12.98 \\
\hline T-036 & $\mathrm{CH}_{3} \mathrm{OOC}$ & $\mathrm{CH}_{3} \mathrm{O}$ & $>128$ & ND \\
\hline T-046 & $\mathrm{H}$ & $\mathrm{H}$ & 58.5 & 46.97 \\
\hline T-063 & $\left(\mathrm{CH}_{3}\right)_{2} \mathrm{CHOOC}$ & $\mathrm{H}$ & 1.4 & 3.04 \\
\hline T-074 & $\mathrm{CH}_{3} \mathrm{CH}_{2} \mathrm{CH}_{2} \mathrm{OOC}$ & $\mathrm{H}$ & 0.87 & 4.62 \\
\hline RMP & & & 0.03 & 0.89 \\
\hline INH & & & 0.12 & $>128$ \\
\hline
\end{tabular}

$\mathrm{ND}$ = not determined; RMP: rifampicin; INH: isoniazid.

Following on our main objective (esters of quinoxaline 1-4-di- $N$-oxide derivatives), 18 compounds of methyl and ethyl ester derivatives were evaluated on M. tuberculosis strain H37Rv. Results are shown in Table 2. All compounds of the methyl ester series showed good anti-M. tuberculosis activity (MIC $<0.35 \mu \mathrm{g} / \mathrm{mL}$ ). SAR analysis of the methyl series, showed that compounds with a carboxylate (methyl and ethyl) group at $\mathrm{R}_{1}$-position and a methyl group at $\mathrm{R}_{2}$-position had high activity (MIC $<0.5 \mu \mathrm{g} / \mathrm{mL}$ ). However, acetyl, benzoyl, and arylcarboxamide groups at $\mathrm{R}_{1}$-position decreased the effect. On the other hand, quinoxaline 1,4-di- $N$-oxide derivatives with a trifluoromethyl group at $\mathrm{R}_{2}$-position also showed good anti-M. tuberculosis activity (MIC $<2.0 \mu \mathrm{g} / \mathrm{mL}$ ) in spite of the presence of a carbonyl group with aliphatic or aromatic substitutes at $\mathrm{R}_{1}$-position. A comparison between analog compounds (T-003 and T-018) with a methyl and trifluoromethyl group at $\mathrm{R}_{2}$-position, respectively, showed that the electronegative properties of trifluoromethyl enhance their biological activity. Compound T-018 showed the best biological activity (MIC $=0.15 \mu \mathrm{g} / \mathrm{mL}$ ), a value similar to the reference drug isoniazid ( $\mathrm{MIC}=0.12 \mu \mathrm{g} / \mathrm{mL}$ ). Also, this compound showed the best activity (low oxygen recovery assay (LORA) MIC $=0.34 \mu \mathrm{g} / \mathrm{mL}$ ) against the NRP M. tuberculosis strain. Analyzing all LORA results of quinoxaline 1,4-di- $\mathrm{N}$-oxide derivatives, these compounds had the same biological behavior on $M$. tuberculosis strain $\mathrm{H} 37 \mathrm{Rv}$; therefore, substitutions at $\mathrm{R}_{1}$ - and $\mathrm{R}_{2}$-position also affect biological activity on the NRP strain.

In the ethyl ester series in general, all quinoxaline 1,4-di- $N$-oxide derivatives showed good anti-M. tuberculosis activity (MIC $<2.5 \mu \mathrm{g} / \mathrm{mL}$ ) except compounds T-026 and T-045, which had ten times less activity (MIC $>22 \mu \mathrm{g} / \mathrm{mL}$ ). These compounds have an aliphatic linear substitution or a free amino group at $\mathrm{R}_{1}$-position with a trifluoromethyl and methyl group at $\mathrm{R}_{2}$-position, respectively. Compound T-015 with a carboxyethyl and methyl group at $\mathrm{R}_{1}$ - and $\mathrm{R}_{2}$-position, respectively, showed a MIC of $0.50 \mu \mathrm{g} / \mathrm{mL}$. In addition, compounds with a trifluoromethyl group at $\mathrm{R}_{2}$-position showed better anti-M. tuberculosis activity with an acetyl or aromatic group at $\mathrm{R}_{1}$-position. Compounds T-007 and T-011 showed MIC values $(0.14$ and $0.10 \mu \mathrm{g} / \mathrm{mL}$ ) similar to that of isoniazid (MIC $=0.12 \mu \mathrm{g} / \mathrm{mL}$ ). These compounds have a thiophene and a naphthyl group, respectively. These groups could consider a bioisostere from a phenyl group present in the best compound (T-018) of the methyl ester series. Additionally, T-007, T-011, and T-018 showed the best effect on the NRP M. tuberculosis strain. An analysis between the methyl and ethyl series showed that a substitution at $\mathrm{R}_{3}$-position does not affect biological activity; for example, compounds T-008 and T-016 showed a similar MIC value. Additionally, the ethyl quinoxaline 1,4-di- $N$-oxide series confirm that substitutions at $\mathrm{R}_{1}$ - and $\mathrm{R}_{2}$-position also affect the biological behavior on the NRP $M$. tuberculosis strain. 
Table 2. Biological activity of methyl and ethyl quinoxaline-7-carboxylate 1,4-di- $N$-oxide derivatives using the MABA against Mycobacterium tuberculosis strain H37Rv and the LORA against the nonreplicating persistent strain.

\begin{tabular}{|c|c|c|c|c|c|}
\hline Code & $\mathbf{R}_{1}$ & $\mathbf{R}_{\mathbf{2}}$ & $\mathbf{R}_{3}$ & MABA MIC $(\mu \mathrm{g} / \mathrm{mL})$ & LORA MIC $(\mu \mathrm{g} / \mathrm{mL})$ \\
\hline T-003 & $\mathrm{COC}_{6} \mathrm{H}_{5}$ & $\mathrm{CH}_{3}$ & $\mathrm{CH}_{3}$ & 3.47 & 1.49 \\
\hline T-004 & CO-phenyl & $\mathrm{CH}_{3}$ & $\mathrm{CH}_{3} \mathrm{CH}_{2}$ & 2.32 & 0.61 \\
\hline T-006 & $\mathrm{COCH}_{3}$ & $\mathrm{CF}_{3}$ & $\mathrm{CH}_{3} \mathrm{CH}_{2}$ & 0.29 & 0.42 \\
\hline T-007 & CO-napthyl & $\mathrm{CF}_{3}$ & $\mathrm{CH}_{3} \mathrm{CH}_{2}$ & 0.14 & 0.43 \\
\hline T-011 & CO-thienyl & $\mathrm{CF}_{3}$ & $\mathrm{CH}_{3} \mathrm{CH}_{2}$ & 0.10 & 0.21 \\
\hline $\mathrm{T}-012$ & $\mathrm{CONHC}_{6} \mathrm{H}_{5}$ & $\mathrm{CH}_{3}$ & $\mathrm{CH}_{3}$ & 1.07 & 0.86 \\
\hline T-013 & $\mathrm{COOCH}_{2} \mathrm{CH}_{3}$ & $\mathrm{CH}_{3}$ & $\mathrm{CH}_{3}$ & 0.47 & 0.54 \\
\hline T-015 & $\mathrm{COOCH}_{2} \mathrm{CH}_{3}$ & $\mathrm{CH}_{3}$ & $\mathrm{CH}_{3} \mathrm{CH}_{2}$ & 0.50 & 0.49 \\
\hline T-018 & CO-phenyl & $\mathrm{CF}_{3}$ & $\mathrm{CH}_{3}$ & 0.15 & 0.34 \\
\hline T-022 & $\mathrm{COOCH}_{3}$ & $\mathrm{CH}_{3}$ & $\mathrm{CH}_{3}$ & 0.29 & 0.56 \\
\hline T-026 & $\mathrm{COCH}_{2} \mathrm{CH}_{3}$ & $\mathrm{CF}_{3}$ & $\mathrm{CH}_{3} \mathrm{CH}_{2}$ & 22.5 & 2.5 \\
\hline T-034 & $\mathrm{COCH}_{3}$ & $\mathrm{CH}_{3}$ & $\mathrm{CH}_{3}$ & 1.1 & 0.7 \\
\hline T-037 & $\mathrm{COOCH}_{2} \mathrm{CH}_{3}$ & $\mathrm{CH}_{2} \mathrm{COOCH}_{2} \mathrm{CH}_{3}$ & $\mathrm{CH}_{3}$ & 1.2 & 1.9 \\
\hline T-038 & $\mathrm{COCH}_{2} \mathrm{CH}_{3}$ & $\mathrm{CF}_{3}$ & $\mathrm{CH}_{3}$ & $<0.4$ & ND \\
\hline T-039 & $\mathrm{COCH}\left(\mathrm{CH}_{3}\right)_{2}$ & $\mathrm{CF}_{3}$ & $\mathrm{CH}_{3}$ & 1.54 & 0.83 \\
\hline $\mathrm{T}-042$ & $\mathrm{COOCH}_{2} \mathrm{CH}_{3}$ & $\mathrm{C}_{6} \mathrm{H}_{5}$ & $\mathrm{CH}_{3}$ & 1.0 & 0.5 \\
\hline $\mathrm{T}-043$ & $\mathrm{COOCH}_{2} \mathrm{CH}_{3}$ & $\mathrm{C}_{6} \mathrm{H}_{5}$ & $\mathrm{CH}_{3} \mathrm{CH}_{2}$ & 0.54 & 0.47 \\
\hline T-045 & $\mathrm{CONH}_{2}$ & $\mathrm{CH}_{3}$ & $\mathrm{CH}_{3} \mathrm{CH}_{2}$ & 29.83 & 100.29 \\
\hline RMP & & & & 0.03 & 0.89 \\
\hline INH & & & & 0.12 & $>128$ \\
\hline
\end{tabular}

ND = not determined; RMP: rifampicin; INH: isoniazid .

Results shown in Table 2 confirm that methyl and ethyl ester groups at $R_{3}$-position on the quinoxaline 1,4-di-N-oxide ring do not produce changes in anti- $M$. tuberculosis activity. However, these results (at $R_{1}$ - and $R_{2}$-position) also suggest that steric effects modify biological activity. Therefore, we proposed obtaining two new series with an aliphatic substituent (isopropyl and n-propyl) at $\mathrm{R}_{3}$-position to confirm a positive, negative, or null effect on biological activity (Table 3). SAR analysis of the isopropyl series confirmed that a carboxylate (methyl and ethyl) group at $R_{1}$-position enhanced anti-M. tuberculosis activity. As in the previous methyl and ethyl series, benzoyl, arylcarboxamide, or amine groups at $\mathrm{R}_{1}$-position reduced the activity with a methyl group at $\mathrm{R}_{2}$-position on the quinoxaline 1,4-di- $N$-oxide ring. Interestingly, an isopropyl group at $\mathrm{R}_{1}$-position drastically decreased biological activity. This confirms that steric effects are important in anti- $M$. tuberculosis activity. Also, in the isopropyl series, compounds with a trifluoromethyl group at $\mathrm{R}_{2}$-position showed the best activity. In particular, compound T-069 showed the best MIC $(0.08 \mu \mathrm{g} / \mathrm{mL})$ of all the quinoxaline 1,4-di- $N$-oxide derivatives. This compound is an analogue of compound T-011 (ethyl series), although compound T-069 had a MIC value ten times higher. Therefore, the isopropyl group at $\mathrm{R}_{3}$-position is a key factor to enhance anti-M. tuberculosis activity. In the n-propyl series, the SAR partner is the same as the previous series (methyl, ethyl and isopropyl). The best compound in this series was T-089 (an analogue of T-011 and T-069) with a MIC of $0.12 \mu \mathrm{g} / \mathrm{mL}$ on strain H37Rv and $0.15 \mu \mathrm{g} / \mathrm{mL}$ on NRP M. tuberculosis strain. A SAR analysis of all esters of quinoxaline 1,4-di- $\mathrm{N}$-oxide is shown in Figure 1. 
Table 3. Biological activity of isopropyl and n-propyl quinoxaline-7-carboxylate 1,4-di- $\mathrm{N}$-oxide derivatives using the MABA against Mycobacterium tuberculosis strain H37Rv and the LORA against nonreplicating persistent strain.

\begin{tabular}{|c|c|c|c|c|c|}
\hline Code & $\mathbf{R}_{\mathbf{1}}$ & $\mathbf{R}_{\mathbf{2}}$ & $\mathbf{R}_{3}$ & MABA MIC $(\mu \mathrm{g} / \mathrm{mL})$ & LORA MIC $(\mu \mathrm{g} / \mathrm{mL})$ \\
\hline T-064 & $\mathrm{COOCH}_{3}$ & $\mathrm{CH}_{3}$ & $\left(\mathrm{CH}_{3}\right)_{2} \mathrm{CH}$ & 0.58 & 0.56 \\
\hline T-065 & $\mathrm{COOCH}_{2} \mathrm{CH}_{3}$ & $\mathrm{CH}_{3}$ & $\left(\mathrm{CH}_{3}\right)_{2} \mathrm{CH}$ & 0.7 & 0.5 \\
\hline T-066 & $\mathrm{COOC}\left(\mathrm{CH}_{3}\right)_{3}$ & $\mathrm{CH}_{3}$ & $\left(\mathrm{CH}_{3}\right)_{2} \mathrm{CH}$ & 68.6 & $>100(77 \%)$ \\
\hline T-067 & $\mathrm{COOCH}_{2} \mathrm{CH}_{3}$ & $\mathrm{CH}_{2} \mathrm{COOCH}_{2} \mathrm{CH}_{3}$ & $\left(\mathrm{CH}_{3}\right)_{2} \mathrm{CH}$ & 3.41 & 2.47 \\
\hline T-069 & CO-thienyl & $\mathrm{CF}_{3}$ & $\left(\mathrm{CH}_{3}\right)_{2} \mathrm{CH}$ & 0.08 & 0.23 \\
\hline T-070 & $\mathrm{COCH}_{3}$ & $\mathrm{CF}_{3}$ & $\left(\mathrm{CH}_{3}\right)_{2} \mathrm{CH}$ & 0.14 & 0.24 \\
\hline T-071 & CO-phenyl & $\mathrm{CF}_{3}$ & $\left(\mathrm{CH}_{3}\right)_{2} \mathrm{CH}$ & 1.19 & 0.64 \\
\hline T-072 & CO-napthyl & $\mathrm{CF}_{3}$ & $\left(\mathrm{CH}_{3}\right)_{2} \mathrm{CH}$ & 0.15 & 0.51 \\
\hline T-073 & CO-furyl & $\mathrm{CF}_{3}$ & $\left(\mathrm{CH}_{3}\right)_{2} \mathrm{CH}$ & 0.7 & 0.6 \\
\hline T-084 & $\mathrm{COCH}_{3}$ & $\mathrm{CH}_{3}$ & $\left(\mathrm{CH}_{3}\right)_{2} \mathrm{CH}$ & 0.8 & 0.6 \\
\hline T-085 & $\mathrm{COCH}\left(\mathrm{CH}_{3}\right)_{2}$ & $\mathrm{CF}_{3}$ & $\left(\mathrm{CH}_{3}\right)_{2} \mathrm{CH}$ & 0.13 & 0.13 \\
\hline T-088 & $\mathrm{COOCH}_{3}$ & $\mathrm{CH}_{3}$ & $\mathrm{CH}_{3} \mathrm{CH}_{2} \mathrm{CH}_{2}$ & 0.14 & 0.27 \\
\hline T-089 & CO-thienyl & $\mathrm{CF}_{3}$ & $\mathrm{CH}_{3} \mathrm{CH}_{2} \mathrm{CH}_{2}$ & 0.12 & 0.15 \\
\hline T-090 & $\mathrm{COOCH}_{2} \mathrm{CH}_{3}$ & $\mathrm{CH}_{3}$ & $\mathrm{CH}_{3} \mathrm{CH}_{2} \mathrm{CH}_{2}$ & 0.8 & ND \\
\hline T-091 & $\mathrm{COC}\left(\mathrm{CH}_{3}\right)_{3}$ & $\mathrm{CH}_{3}$ & $\mathrm{CH}_{3} \mathrm{CH}_{2} \mathrm{CH}_{2}$ & $>100(33 \%)$ & ND \\
\hline T-097 & CONH-phenyl & $\mathrm{CH}_{3}$ & $\left(\mathrm{CH}_{3}\right)_{2} \mathrm{CH}$ & $>20(6 \%)$ & $>20(33 \%)$ \\
\hline T-098 & CO-phenyl & $\mathrm{CH}_{3}$ & $\left(\mathrm{CH}_{3}\right)_{2} \mathrm{CH}$ & 4.59 & 2.87 \\
\hline T-107 & $\mathrm{COC}\left(\mathrm{CH}_{3}\right)_{3}$ & $\mathrm{C}\left(\mathrm{CH}_{3}\right)_{3}$ & $\left(\mathrm{CH}_{3}\right)_{2} \mathrm{CH}$ & 2.1 & ND \\
\hline T-108 & $\mathrm{CONH}_{2}$ & $\mathrm{CH}_{3}$ & $\left(\mathrm{CH}_{3}\right)_{2} \mathrm{CH}$ & 22.5 & ND \\
\hline T-111 & $\mathrm{COCH}\left(\mathrm{CH}_{3}\right)_{2}$ & $\mathrm{CF}_{3}$ & $\mathrm{CH}_{3} \mathrm{CH}_{2} \mathrm{CH}_{2}$ & 1.5 & ND \\
\hline T-112 & $\mathrm{COOCH}_{2} \mathrm{CH}_{3}$ & $\mathrm{COCOOCH}_{2} \mathrm{CH}_{3}$ & $\mathrm{CH}_{3} \mathrm{CH}_{2} \mathrm{CH}_{2}$ & 1.4 & ND \\
\hline T-113 & $\mathrm{COCH}_{3}$ & $\mathrm{CF}_{3}$ & $\mathrm{CH}_{3} \mathrm{CH}_{2} \mathrm{CH}_{2}$ & 3.0 & ND \\
\hline T-114 & CO-furyl & $\mathrm{CF}_{3}$ & $\mathrm{CH}_{3} \mathrm{CH}_{2} \mathrm{CH}_{2}$ & 2.9 & ND \\
\hline T-115 & CO-phenyl & $\mathrm{CF}_{3}$ & $\mathrm{CH}_{3} \mathrm{CH}_{2} \mathrm{CH}_{2}$ & 1.5 & ND \\
\hline T-124 & $\mathrm{COOCH}_{2} \mathrm{CH}_{3}$ & $\mathrm{CF}_{3}$ & $\mathrm{CH}_{3} \mathrm{CH}_{2} \mathrm{CH}_{2}$ & 3.0 & ND \\
\hline T-125 & CONH-phenyl & $\mathrm{CH}_{3}$ & $\mathrm{CH}_{3} \mathrm{CH}_{2} \mathrm{CH}_{2}$ & 12.3 & ND \\
\hline T-126 & $\mathrm{COCH}_{3}$ & $\mathrm{CH}_{3}$ & $\mathrm{CH}_{3} \mathrm{CH}_{2} \mathrm{CH}_{2}$ & 3.0 & ND \\
\hline T-130 & $\mathrm{CONH}_{2}$ & $\mathrm{CH}_{3}$ & $\mathrm{CH}_{3} \mathrm{CH}_{2} \mathrm{CH}_{2}$ & 2.9 & ND \\
\hline T-132 & CO-phenyl & $\mathrm{CH}_{3}$ & $\mathrm{CH}_{3} \mathrm{CH}_{2} \mathrm{CH}_{2}$ & 2.3 & ND \\
\hline RMP & & & & 0.03 & 0.89 \\
\hline INH & & & & 0.12 & $>128$ \\
\hline
\end{tabular}

$\mathrm{ND}=$ not determined; RMP: rifampicin; INH: isoniazid

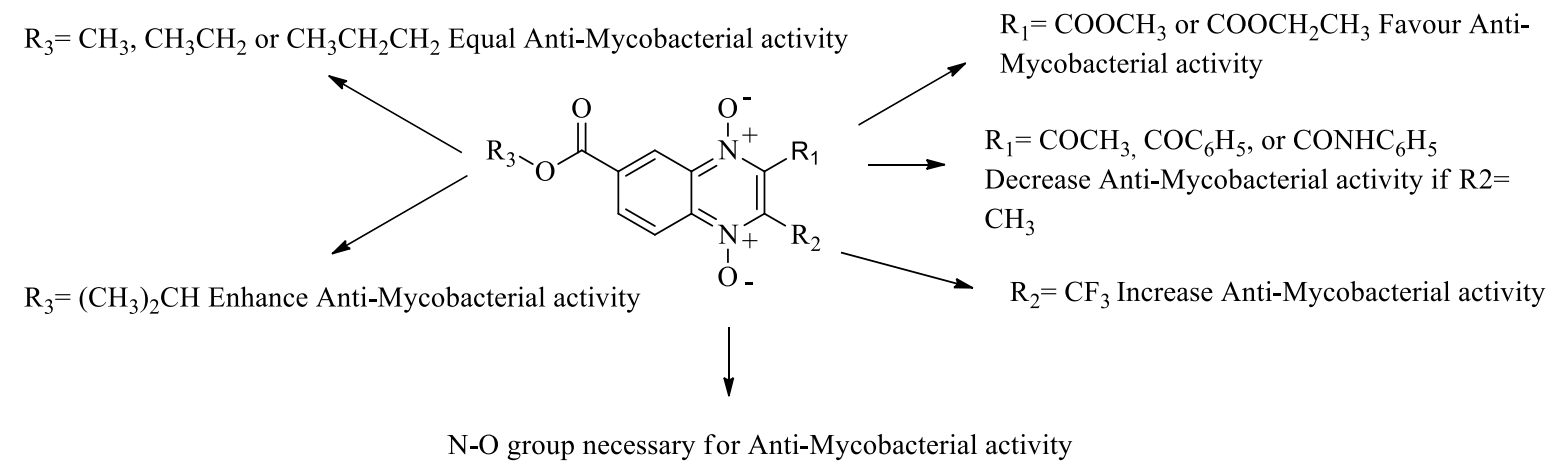

Figure 1. A structure-activity relationship analysis from esters of quinoxaline-7-carboxylate 1,4-di- $N$-oxide as antimycobacterial agents. 
Finally, eight compounds ( $\mathrm{MIC}<0.30 \mu \mathrm{g} / \mathrm{mL}$ ) from all esters of quinoxaline 1,4-di-N-oxide derivatives were selected to be tested against monoresistant $M$. tuberculosis and some nontuberculous Mycobacterium (NTM) strains. Additionally, the half maximal cytotoxicity concentration $\left(\mathrm{CC}_{50}\right)$ on mammalian cell macrophages and the selectivity index (SI) were determined. The results are shown in Table 4. In general, all compounds had similar MICs values on M. tuberculosis and monoresistant strains. This suggests that the mechanism of action of esters of quinoxaline 1,4-di- $N$-oxide derivatives is different from reference drugs. Although our compounds had good antimycobacterial activity, none of the quinoxaline 1,4-di-N-oxide derivatives showed better MIC values than rifampicin in monoresistant strains, except against M. tuberculosis strain H37Rv RR. Compounds T-022 and T-088 showed the best biological activity on this strain and the best SI value (SI > 70). Activity against the NTM strains was not as good as with the tuberculosis strains; only compound T-085 was active against all NTM strains, and the slow grower NTM M. avium strain was susceptible to all compounds except T-088. These results confirm that these esters of quinoxaline 1,4-di- $N$-oxide can be considered for development of new pharmacological options for the treatment of TB susceptible or drug resistant.

\subsection{Inhibitory Assay}

DNA gyrases are enzymes within the class of type II topoisomerase, which form a heterotetramer composed of four subunits encoded by the $g y r A$ and $g y r B$ gene [17]. This enzyme catalyzes the unwinding of double-stranded DNA through the introduction of negative supercoils. This process is blocked by fluoroquinolones causing the formation of covalent enzyme-DNA adducts, which leads to chromosome fragmentation and cell death in bacteria. Thus, DNA gyrases are known targets for fluoroquinolones. However, some studies have hypothesized that quinoxaline derivatives could inhibit DNA gyrases from M. tuberculosis $[14,18]$. Keeping in pace with these conjectures, we analyzed the inhibitory effect of esters of quinoxaline 1,4-di- $N$-oxide derivatives on $M$. tuberculosis gyrase supercoiling. The compounds tested were: T-003, T-013, T-018, and T-038 from the methyl series; T-011 and T-012 from ethyl series; T064, T-069, and T-108 from isopropyl series; and T-114 and T-125 from n-propyl series. However, none of the compounds showed an inhibitory effect on M. tuberculosis gyrase supercoiling at $50 \mu \mathrm{M}$. Moxifloxacin, the positive control, showed an $\mathrm{IC}_{50}$ value of $9.44 \mu \mathrm{M}$. The compounds T-011, T-018, T-038, T-069, and T-114 showed the trifluoromethyl group at $R_{2}$-position, with this not interfering with the union of DNA-protein. This was observed in earlier studies employing carcinogenic polycyclic aromatic compounds with trifluoromethyl group [19]. Based on these results, esters of quinoxaline 1,4-di-N-oxide derivatives may not be $M$. tuberculosis gyrase supercoiling inhibitors, suggesting that these esters of quinoxaline 1,4-di- $N$-oxide derivatives have another mechanism of action that needs to be explored. 
Table 4. Minimum inhibitory concentration (MIC in $\mu \mathrm{g} / \mathrm{mL}$ ) of esters of quinoxaline 1,4-di- $N$-oxide derivatives on monoresistant $M$. tuberculosis and some nontuberculous Mycobacterium strains.

\begin{tabular}{|c|c|c|c|c|c|c|c|c|c|c|c|c|}
\hline Code & M. $t b$ H37Rv & M. $t b$ H37Rv IR & M. $t b$ H37Rv ER & M. $t b$ H37Rv SR & M. $t b$ H37Rv RR & M. fortuitum & M. abscessus & M. chelonae & M. avium & M. smegmatis & $\mathrm{CC}_{50}$ & SI \\
\hline T-006 & 2.0 & 1.25 & 1.25 & 5 & 1.25 & $>10$ & $>10$ & $>10$ & 2.5 & $>10$ & $>100^{+}$ & $>50$ \\
\hline T-011 & 0.5 & $<0.31$ & $<0.31$ & 0.625 & $<0.31$ & 2.5 & $>10$ & $>10$ & $<0.31$ & 0.62 & $1.67^{-}$ & 3.34 \\
\hline $\mathrm{T}-018$ * & 1.0 & 0.62 & 0.62 & 1.25 & 0.625 & $>10$ & 5 & $>10$ & 2.5 & 2.5 & $35.37^{-}$ & 35.37 \\
\hline $\mathrm{T}-022$ * & 0.5 & 0.62 & 0.62 & 0.625 & $<0.31$ & 2.5 & $>10$ & 2.5 & 2.5 & 0.62 & $86.25^{+}$ & 172.5 \\
\hline $\mathrm{T}-069$ & 1.0 & 0.62 & 1.25 & 1.25 & 1.25 & $>10$ & $>10$ & 2.5 & 5 & $>10$ & $41.26^{-}$ & 41.26 \\
\hline $\mathrm{T}-085$ & 1.0 & $<0.31$ & $<0.31$ & 1.25 & 0.625 & 2.5 & 2.5 & 5 & 0.62 & 1.25 & $45.42^{-}$ & 45.42 \\
\hline $\mathrm{T}-088^{\circ}$ & 0.5 & 0.62 & $<0.31$ & 0.625 & $<0.31$ & $>10$ & $>10$ & $>10$ & $>10$ & 2.5 & $36.51^{+}$ & 73.02 \\
\hline $\mathrm{T}-089^{\circ}$ & 0.5 & $<0.31$ & 0.625 & 1.25 & 1.25 & $>10$ & $>10$ & $>10$ & 0.62 & $>10$ & $24.27^{-}$ & 48.54 \\
\hline RMP & $<0.06$ & $<0.06$ & $<0.06$ & $<0.06$ & $>2.0$ & ND & ND & ND & ND & ND & ND & $\mathrm{ND}$ \\
\hline
\end{tabular}

${ }^{*}$ is methyl ester of quinoxaline 1,4-di- $\mathrm{N}$-oxide derivative; $\sim$ is ethyl ester of quinoxaline 1,4 -di- $\mathrm{N}$-oxide derivative; ; is isopropyl ester of quinoxaline 1,4 -di- $\mathrm{N}$-oxide derivative; ${ }^{\circ}$ is n-propyl ester of quinoxaline 1,4-di-N-oxide derivative; $\mathrm{RMP}=$ rifampicin; $\mathrm{IR}=$ isoniazid resistant; $\mathrm{ER}=$ ethambutol resistant; $\mathrm{SR}=$ streptomycin resistant; $\mathrm{RR}=$ rifampicin resistant; $\mathrm{ND}=$ not determined; $\mathrm{CC}_{50}=$ cytotoxicity on macrophage cell ${ }^{-}$at $6 \mathrm{~h},{ }^{+}$at $96 \mathrm{~h} ; \mathrm{SI}=$ selectivity index. 


\subsection{Stability Analysis by UPLC-MS}

The presence of ester groups at 7-position on the quinoxaline 1,4-di- $\mathrm{N}$-oxide ring could suggest that these compounds will not be stable when tested in animal models. Therefore, a simple assay to test the stability of compounds T-018 and T-069-methyl and isopropyl ester derivatives, respectively-was performed using ultra performance liquid chromatography-tandem mass spectrometry (UPLC-MS). The results are shown in Figure 2. Figure 2A, shows only one peak with a time retention of $1.26 \mathrm{~min}$ corresponding to compound T-018 $(m / z=393.02)$. After $12 \mathrm{~h}$ in human plasma, two new low intensity peaks are seen (time retention $=0.72$ and $2.05 \mathrm{~min}$ ) (Figure 2a). These peaks, which increased in intensity after $24 \mathrm{~h}$ (Figure $2 \mathrm{~b}$ ) represented 4.82 and $4.12 \%$, respectively, suggesting a low degradation of compound T-018. In Figure 2B, only one peak was observed with a time retention of $1.51 \mathrm{~min}$ corresponding to compound T-069 $(\mathrm{m} / \mathrm{z}=427.02)$. After $12 \mathrm{~h}$, a second peak is seen at $0.62 \mathrm{~min}$ (Figure 2c). Finally, after $24 \mathrm{~h}$, another peak occurs at $2.72 \mathrm{~min}$ (Figure 2d). Both peaks at $24 \mathrm{~h}$ represent $0.83 \%$ and $2.20 \%$, respectively, suggesting that T- 069 had a lower degradation. These results show that esters of quinoxaline 1,4-di- $\mathrm{N}$-oxide are stable in human plasma after $24 \mathrm{~h}$.

(a) $\mathrm{T}-018,12 \mathrm{~h}$ in human plasma at $37^{\circ} \mathrm{C}$

(A) Compound T-018

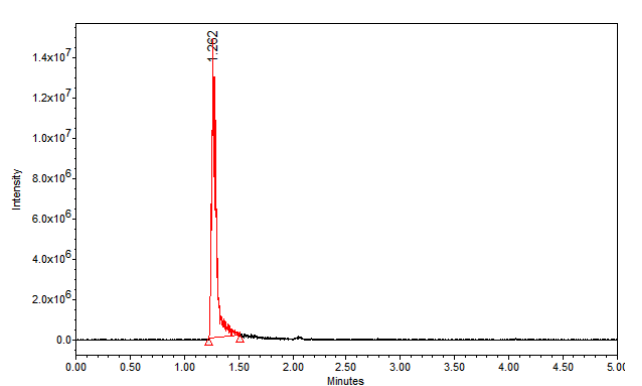

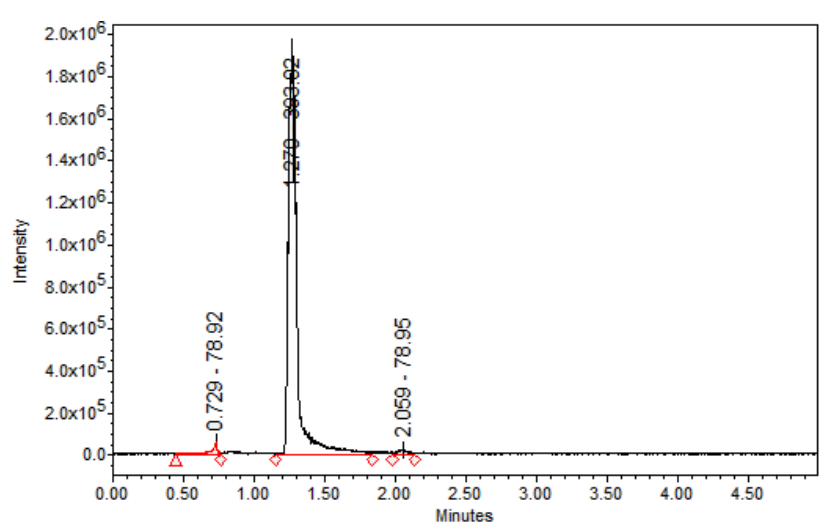

(b) T-018, $24 \mathrm{~h}$ in human plasma at $37^{\circ} \mathrm{C}$

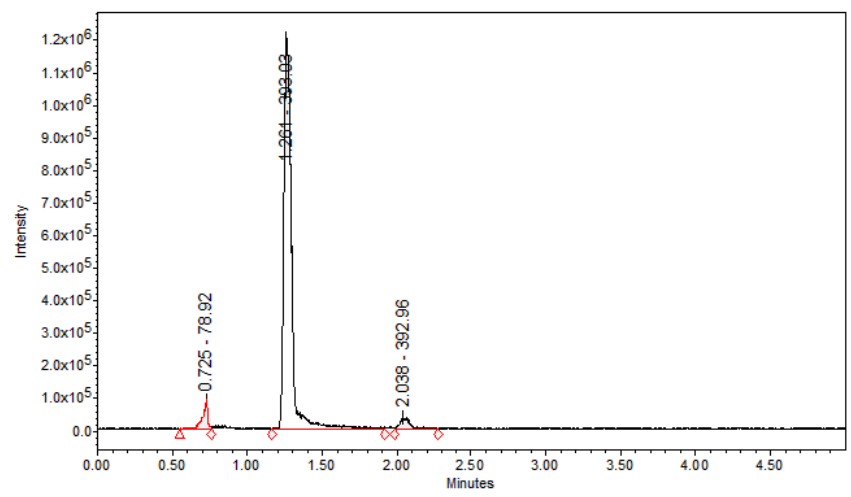

Figure 2. Cont. 
(c) T-069, $12 \mathrm{~h}$ in human plasma at $37^{\circ} \mathrm{C}$

(B) Compound T-069

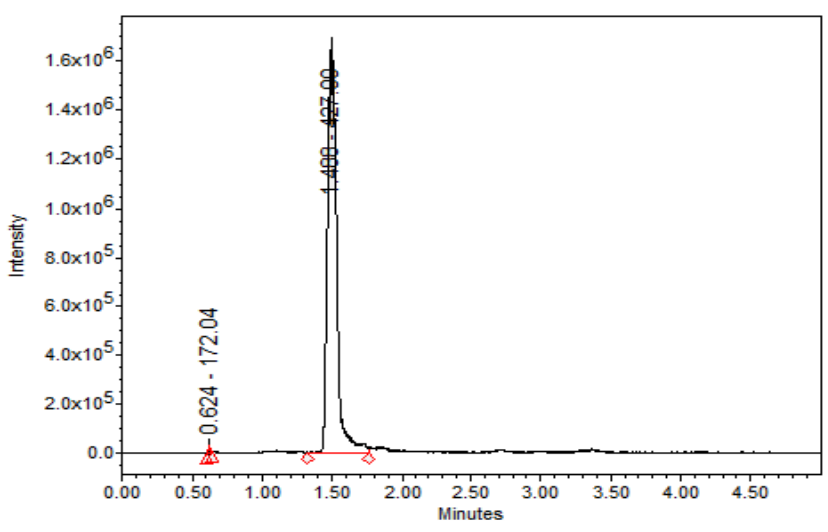

(d) T-069, $24 \mathrm{~h}$ in human plasma at $37^{\circ} \mathrm{C}$
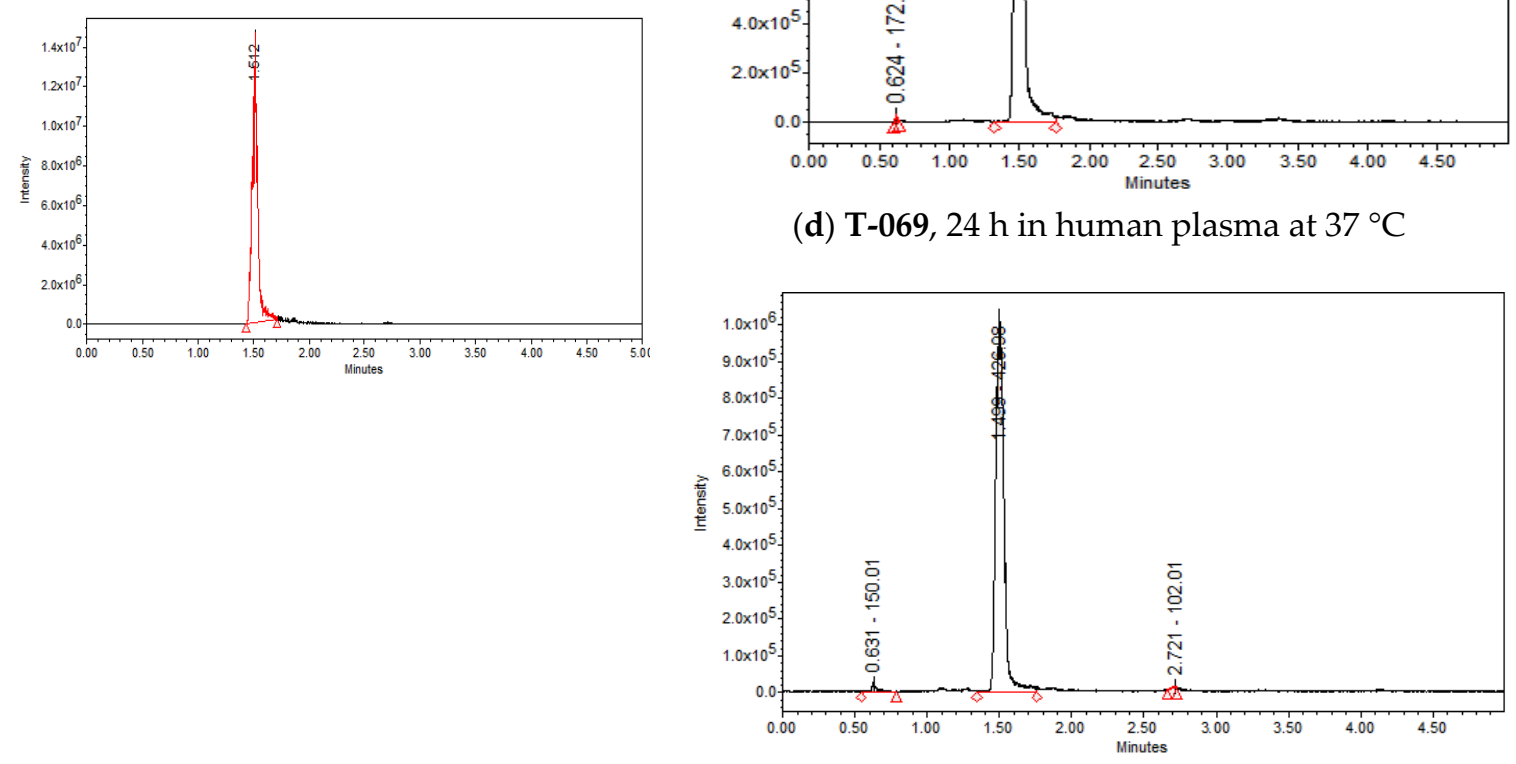

Figure 2. Ultra performance liquid chromatography (UPLC) of (A) compound T-018 and (B) compound T-069. (a) T-018 after $12 \mathrm{~h}$ in human plasma at $37^{\circ} \mathrm{C}$; (b) T-018 after $24 \mathrm{~h}$ in human plasma ${ }^{\circ} \mathrm{C}$; (c) T-069 after $12 \mathrm{~h}$ in human plasma at $37^{\circ} \mathrm{C}$; and (d) T-069 after $24 \mathrm{~h}$ in human plasma at $37^{\circ} \mathrm{C}$.

\section{Materials and Methods}

\subsection{Chemical Synthesis}

All compounds from the methyl, ethyl, isopropyl, and n-propyl ester series of quinoxaline 1,4- $\mathrm{N}$-oxide were obtained following the procedure previously reported by Gomez-Caro et al. [20]. These compounds were analyzed by IR, ${ }^{1} \mathrm{H}-\mathrm{NMR}$ and elemental analysis and have been previously reported [21-24].

\subsection{Antitubercular Assays}

The antitubercular activity (MIC values) was assessed in vitro against Mycobacterium tuberculosis strain H37Rv ATCC 27294 according to a modified microplate Alamar blue assay (MABA) [25]. The assays were performed in triplicate independent experiments. The standard M. tuberculosis strain $\mathrm{H} 37 \mathrm{Rv}$ was tested with known reference drugs rifampicin and isoniazid. The lowest drug concentration effecting an inhibition of $90 \%$ was considered as MIC. Additionally, an in vitro LORA test was done following the procedure previously reported by Cho et al. [26]. Antituberculosis activity testing against drug monoresistant strains (ATCC35822, ATCC35838, ATCC35837, and ATCC35820) or NTM clinical isolates was performed as described earlier by Luna-Herrera et al. [27]. 


\subsection{Selectivity Index}

The determination of the half maximal cytotoxicity concentration $\left(\mathrm{CC}_{50}\right)$ of the compounds T-006, T-011, T-018, T-022, T-069, T-085, T-088, and T-089 was carried out on the mouse macrophage cell line J774A.1 (ATCC TIB-67). Briefly, cell monolayers were prepared in 96-well plates with 10,000 cells per well in Ham's F-12 medium supplemented with 10\% Fetal bovine serum (FBS, By products, Guadalajara, Mexico) and antibiotics (penicillin and gentamicin). Five concentrations from 100 to $0.5 \mu \mathrm{g} / \mathrm{mL}$ of each of the compounds were tested. The cells were incubated for a period of $6 \mathrm{~h}\left(^{-}\right)$or $96 \mathrm{~h}\left(^{+}\right)$. Before completing this period, $20 \mu \mathrm{L}$ of Alamar blue solution was added to each well, quantifying the relative fluorescence units in a fluorometer (Fluoroskan Ascent FL, Labsystems). The percentage of cytotoxicity at each concentration was determined by comparing the values against the control of cells without treatment. The $\mathrm{CC}_{50}$ was determined with the Probit regression analysis (MedCalc Statistical Software version 18.5, Ostend, Belgium). Selectivity index was calculated as the ratio of the $\mathrm{CC}_{50}$ on the macrophage cell line J774A.1 and the MIC value against $M$. tuberculosis strain H37Rv [28].

\subsection{Enzymatic Assay}

\subsubsection{Assay Set Up}

The activity of the enzyme was determined prior to the testing of the quinoxaline 1,4-di- $\mathrm{N}$-oxide derivatives and $1 \mathrm{U}$ was defined as the amount of enzyme required to just fully supercoil the substrate under test conditions. Compounds were tested at $50 \mu \mathrm{M}$. Final DMSO concentration in the assays was $1 \%(v / v)$.

\subsubsection{M. tuberculosis Gyrase Supercoiling}

$1 \mathrm{U}$ of $M$. tuberculosis gyrase (GyrA and Gyr B subunits) (final concentration in assay $50 \mathrm{nM}$ ) was incubated with $0.5 \mu \mathrm{g}$ of relaxed pBR322 DNA in a $30 \mu \mathrm{L}$ reaction at $37^{\circ} \mathrm{C}$ for 30 min under the following conditions: $50 \mathrm{mM}$ HEPES. $\mathrm{KOH}$ (pH 7.9), $6 \mathrm{mM}$ magnesium acetate, $4 \mathrm{mM}$ DTT, $1 \mathrm{mM}$ ATP, $100 \mathrm{mM}$ potassium glutamate, $2 \mathrm{mM}$ spermidine and $0.05 \mathrm{mg} / \mathrm{mL}$ albumin.

Each reaction was stopped by the addition of $30 \mu \mathrm{L}$ chloroform/iso-amyl alcohol (26:1) and $20 \mu \mathrm{L}$ Stop Dye ( $40 \%$ sucrose, $100 \mathrm{mM}$ Tris. $\mathrm{HCl}$ (pH 7.5), $10 \mathrm{mM}$ EDTA, $0.5 \mu \mathrm{g} / \mathrm{mL}$ bromophenol blue), before being loaded on a 1.0\% TAE (Tris.acetate $0.04 \mathrm{mM}$, EDTA $0.002 \mathrm{mM}$ ) gel run at $80 \mathrm{~V}$ for $2 \mathrm{~h}$.

\subsubsection{Data Acquisition and Analysis}

Bands were visualized by ethidium staining for $10 \mathrm{~min}$, destained for $10 \mathrm{~min}$ in water, analyzed by gel documentation equipment (Syngene, Cambridge, UK), and quantified using Syngene software (Genetools version 4.00 (1997-1998), Syngene, A division of Synoptics Corp, Cambridge, UK).

Raw gel data (fluorescent band volumes) collected from Syngene's GeneTools gel analysis software were converted to a $\%$ of the $100 \%$ control (the supercoiled enzyme plus DMSO control DNA band). These were analyzed using SigmaPlot Version 13.0 (Systat Software Inc., London, UK; 2016).

\subsection{Chromatographic Analysis}

Compounds T-018 and T-069 were selected to analyze their stability in human plasma. A total of $1 \mathrm{mg}$ of each of the two compounds was dissolved in $1 \mathrm{~mL}$ of dichlorometane. Then, $0.1 \mathrm{~mL}$ was added to $0.9 \mathrm{~mL}$ of $0.1 \%$ formic acid in acetonitrile for analysis by UPLC with an ACQUITY QDa mass detector from Waters (Milford, MA, USA) under the following conditions: column: ACQUITY $\mathrm{UPLC}^{\circledR} \mathrm{BEH} \mathrm{C}_{18} 1.7 \mu \mathrm{m}, 2.1 \times 100 \mathrm{~mm}$; mobile phase: $0.1 \%$ formic acid/acetonitrile; run time: $5 \mathrm{~min}$; flow rate: $0.3 \mathrm{~mL} / \mathrm{min}$; injection volume: $0.5 \mu \mathrm{L}$; temperature: $40^{\circ} \mathrm{C}$. After that, $3 \mathrm{~mL}$ of human plasma was obtained from a volunteer under medical supervision and following the standard procedures. Then, $1 \mathrm{mg}$ of T-018 and T-069 were dissolved with DMSO 2\% and added to $1 \mathrm{~mL}$ of human plasma. 
Samples were incubated at $37^{\circ} \mathrm{C}$ for 12 and $24 \mathrm{~h}$. T-018 and T-069 were obtained by liquid extraction with dichloromethane $(10 \mathrm{~mL})$ three times and the solvent was eliminated for vacuum pressure. After that, $1 \mathrm{~mL}$ of dichlorometane was added and $0.1 \mathrm{~mL}$ was added to $0.9 \mathrm{~mL}$ of $0.1 \%$ formic acid in acetonitrile and analyzed by UPLC-MS. Percentage of degradation was calculated considering the area under the curve of each peak/the area under the curve of all peaks $\times 100 \%$ at $24 \mathrm{~h}$ only.

\section{Conclusions}

In this study, our results confirmed that esters of quinoxaline 1,4-di- $N$-oxide have good anti- $M$. tuberculosis activity (MIC $<5 \mu \mathrm{g} / \mathrm{mL}$ ) except for five compounds (T-045, ethyl series; T-066 and T-108, isopropyl series; T-091 and T-0125, n-propyl series). Additionally, the best compounds (T-007, T-011, T-018, T-069, T-070, T-072, T-085, and T-088) with a MIC value of $\leq 0.15 \mu \mathrm{g} / \mathrm{mL}$ showed biological activity on both the nonreplicative cells and $M$. tuberculosis monoresistant strains. Structure-activity analysis showed that the compounds with better biological activity were obtained when carboxylate, trifluoromethyl, and isopropyl groups were present at $R_{1}, R_{2}$ and $R_{3}$-position, respectively, on the quinoxaline 1,4-di- $\mathrm{N}$-oxide ring. An enzymatic assay showed that these compounds cannot inhibit M. tuberculosis gyrase supercoiling. Also, these compounds showed a low degradation in human plasma. Therefore, esters of quinoxaline 1,4-di- $\mathrm{N}$-oxide are a good option for developing new antitubercular agents.

Author Contributions: I.P., A.M., and G.R. conceived and designed the experiments; J.L.-H., M.G.A.-A., A.L.-P., E.F.-R., S.F., and B.W. evaluated the biological activity against M. tuberculosis H37Rv, M. tuberculosis monoresistant strains; E.E.L.-R. and A.D.P.-G. carried out the chromatographic analysis; and I.P. and G.R. wrote the paper. All authors read and approved the final manuscript.

Funding: This research was funded by Secretaria de Investigación y Posgrado-Instituto Politécnico Nacional, grant number (G.R.: SIP-SIP-20170207 and SIP-20180306; J.L.-H.: 20170126 and 20180411; and M.G.A.-A.: 20170230 and 20180324).

Acknowledgments: Gildardo Rivera, Maria Guadalupe Aguilera-Arreola and Julieta Luna-Herrera hold a scholarship from the "Comisión de Operación y Fomento de Actividades Académicas" (COFAA-IPN) and "Programa de Estímulos al Desempeño de los Investigadores" (EDI-IPN).

Conflicts of Interest: All participants declare no conflict of interest.

\section{References}

1. World Health Organization. Tuberculosis. 2014. Available online: http:/ /www.who.int/topics/tuberculosis / en/ (accessed on 1 May 2015).

2. Falzon, D.; Mirzayev, F.; Wares, F.; Baena, I.G.; Zignol, M.; Linh, N.; Weyer, K.; Jaramillo, E.; Floyd, K.; Raviglione, M. Multidrug-resistant tuberculosis around the world: What progress has been made? Eur. Respir. J. 2015, 45, 150-160. [CrossRef] [PubMed]

3. Oyewale, O.A. Present status of quinoxaline motifs: Excellent pathfinders in therapeutic medicine. Eur. J. Med. Chem. 2014, 85, 688-715.

4. Carta, A.; Paglietti, G.; Rahbar Nikookar, M.E.; Sanna, P.; Sechi, L.; Zanetti, S. Novel substituted quinoxaline 1,4-dioxides with in vitro antimycobacterial and anticandida activity. Eur. J. Med. Chem. 2002, 37, 355-366. [CrossRef]

5. Ortega, M.A.; Montoya, M.E.; Jaso, A.; Zarranz, B.; Tirapu, I.; Aldana, I.; Monge, A. Antimycobacterial activity of new quinoxaline-2-carbonitrile and quinoxaline-2-carbonitrile 1,4-di- $\mathrm{N}$-oxide derivatives. Pharmazie 2001, 56, 205-207. [CrossRef] [PubMed]

6. Villar, R.; Vicente, E.; Solano, B.; Pérez-Silanes, S.; Aldana, I.; Maddry, J.A.; Lenaerts, A.J.; Franzblau, S.G.; Cho, S.H.; Monge, A.; et al. In vitro and in vivo antimycobacterial activities of ketone and amide derivatives of quinoxaline 1,4-di-N-oxide. J. Antimicrob. Chemother. 2008, 62, 547-554. [CrossRef] [PubMed]

7. Vicente, E.; Pérez-Silanes, S.; Lima, L.M.; Ancizu, S.; Burguete, A.; Solano, B.; Villar, R.; Aldana, I.; Monge, A. Selective activity against Mycobacterium tuberculosis of new quinoxaline 1,4-di-N-oxides. Bioorg. Med. Chem. 2009, 17, 385-389. [CrossRef] [PubMed] 
8. Jaso, A.; Zarranz, B.; Aldana, I.; Monge, A. Synthesis of new 2-acetyl and 2-benzoyl quinoxaline 1,4-di-N-oxide derivatives as anti-Mycobacterium tuberculosis agents. Eur. J. Med. Chem. 2003, 38, 791-800. [CrossRef]

9. Vicente, E.; Villar, R.; Burguete, A.; Solano, B.; Pérez-Silanes, S.; Aldana, I.; Maddry, J.A.; Lenaerts, A.J.; Franzblau, S.G.; Cho, S.H.; et al. Efficacy of quinoxaline-2-carboxylate 1,4-di- $\mathrm{N}$-oxide derivatives in experimental tuberculosis. Antimicrob. Agents Chemother. 2008, 52, 3321-3326. [CrossRef] [PubMed]

10. Pan, Y.; Li, P.; Xie, S.; Tao, Y.; Chen, D.; Dai, M.; Hao, H.; Huang, L.; Wang, Y.; Wang, L.; et al. Synthesis, 3D-QSAR analysis and biological evaluation of quinoxaline 1,4-di- $N$-oxide derivatives as antituberculosis agents. Bioorg. Med. Chem. Lett. 2016, 26, 4146-4153. [CrossRef] [PubMed]

11. Torres, E.; Moreno, E.; Ancizu, S.; Barea, C.; Galiano, S.; Aldana, I.; Monge, A.; Pérez-Silanes, S. New 1,4-di-N-oxide-quinoxaline-2-ylmethylene isonicotinic acid hydrazide derivatives as anti-Mycobacterium tuberculosis agents. Bioorg. Med. Chem. Lett. 2011, 21, 3699-3703. [CrossRef] [PubMed]

12. Ramalingam, P.; Ganapaty, S.; Rao, C.B. In vitro antitubercular and antimicrobial activities of 1-substituted quinoxaline-2,3(1H,4H)-diones. Bioorg. Med. Chem. Lett. 2010, 20, 406-408. [CrossRef] [PubMed]

13. Kumar, K.S.; Rambabu, D.; Sandra, S.; Kapavarapu, R.; Krishna, G.R.; Basaveswara Rao, M.V.; Chatti, K.; Reddy, C.M.; Misra, P.; Pal, M. $\mathrm{AlCl}_{3}$ induced (hetero)arylation of 2,3-dichloroquinoxaline: A one-pot synthesis of mono/disubstituted quinoxalines as potential antitubercular agents. Bioorg. Med. Chem. 2012, 20, 1711-1722. [CrossRef] [PubMed]

14. Radwan, A.A.; Abdel-Mageed, W.M. In silico studies of quinoxaline-2-carboxamide 1,4-di- $N$-oxide derivatives as antimycobacterial agents. Molecules 2014, 19, 2247-2260. [CrossRef] [PubMed]

15. Xu, Y.; Wu, F.; Yao, Z.; Zhang, M.; Jiang, S. Synthesis of quinoxaline 1,4-di-N-oxide analogues and crystal structure of 2-carbomethoxy-3-hydroxyquinoxaline-di-N-oxide. Molecules 2011, 16, 6894-6901. [CrossRef] [PubMed]

16. Dos Santos Fernandes, G.F.; de Souza, P.C.; Moreno-Viguri, E.; Santivañez-Veliz, M.; Paucar, R.; Pérez-Silanes, S.; Chegaev, K.; Guglielmo, S.; Lazzarato, L.; Fruttero, R.; et al. Design, Synthesis, and Characterization of $\mathrm{N}$-Oxide-Containing Heterocycles with in Vivo Sterilizing Antitubercular Activity. J. Med. Chem. 2017, 60, 8647-8660. [CrossRef] [PubMed]

17. Blower, T.R.; Williamson, B.H.; Kerns, R.J.; Berger, J.M. Crystal Structure and Stability of Gyrase-Fluoroquinolone Cleaved Complexes from Mycobacterium Tuberculosis. Proc. Natl. Acad. Sci. USA 2016, 113, 1706-1713. [CrossRef] [PubMed]

18. Peraman, R.; Kuppusamy, R.; Killi, S.K.; Reddy, Y.P. New Conjugates of Quinoxaline as Potent Antitubercular and Antibacterial Agents. Research article. Int. J. Med. Chem. 2016, 2016, 6471352. [CrossRef] [PubMed]

19. Boyd, G.W.; Coombs, M.M.; Baird, W.M. The presence of a trifluoromethyl rather than a methyl substituent in the bay-region greatly decreases the DNA-binding and tumour-initiating activity of the cyclopenta[ $\alpha$ ]phenanthren-17-ones. Carcinogenesis 1995, 16, 2543-2547. [CrossRef] [PubMed]

20. Gómez-Caro, L.C.; Sánchez-Sánchez, M.; Bocanegra-García, V.; Rivera, G.; Monge, A. Synthesis of quinoxaline 1,4-di-N-oxide derivatives on solid support using room temperature and microwave-assisted solvent-free procedures. Química Nova 2011, 34, 1147-1151. [CrossRef]

21. Duque-Montaño, B.E.; Gómez-Caro, L.C.; Sanchez-Sanchez, M.; Monge, A.; Hernández-Baltazar, E.; Rivera, G.; Torres-Angeles, O. Synthesis and in vitro evaluation of new ethyl and methyl quinoxaline-7-carboxylate 1,4-di-N-oxide against Entamoeba histolytica. Bioorg. Med. Chem. 2013, 21, 4550-4558. [CrossRef] [PubMed]

22. Villalobos-Rocha, J.C.; Sánchez-Torres, L.; Nogueda-Torres, B.; Segura-Cabrera, A.; García-Pérez, C.A.; Bocanegra-García, V.; Palos, I.; Monge, A.; Rivera, G. Anti-Trypanosoma cruzi and anti-leishmanial activity by quinoxaline-7-carboxylate 1,4-di-N-oxide derivatives. Parasitol. Res. 2014, 113, 2027-2035. [CrossRef] [PubMed]

23. Rivera, G.; Andrade-Ochoa, S.; Romero, M.S.O.; Palos, I.; Monge, A.; Sanchez-Torres, L.E. Ester of Quinoxaline-7-carboxylate 1,4-di-N-oxide as Apoptosis Inductors in K-562 Cell Line: An in vitro, QSAR and DFT Study. Anticancer Agents Med. Chem. 2017, 17, 682-691. [CrossRef] [PubMed] 
24. Chacón-Vargas, K.F.; Nogueda-Torres, B.; Sánchez-Torres, L.E.; Suarez-Contreras, E.; Villalobos-Rocha, J.C.; Torres-Martinez, Y.; Lara-Ramirez, E.E.; Fiorani, G.; Krauth-Siegel, R.L.; Bolognesi, M.L.; et al. Trypanocidal Activity of Quinoxaline 1,4 Di-N-oxide Derivatives as Trypanothione Reductase Inhibitors. Molecules 2017, 22, 220. [CrossRef] [PubMed]

25. Franzblau, S.G.; Witzig, R.S.; McLaughlin, J.C.; Torres, P.; Madico, G.; Hernandez, A.; Degnan, M.T.; Cook, M.B.; Quenzer, V.K.; Ferguson, R.M.; et al. Rapid, low-technology MIC determination with clinical Mycobacterium tuberculosis isolates by using the microplate Alamar Blue assay. J. Clin. Microbiol. 1998, 36, 362-366. [PubMed]

26. Cho, S.H.; Warit, S.; Wan, B.; Hwang, C.H.; Pauli, G.F.; Franzblau, S.G. Low-Oxygen-Recovery Assay for High-Throughput Screening of Compounds against Nonreplicating Mycobacterium tuberculosis. Antimicrob. Agents Chemother. 2007, 51, 1380-1385. [CrossRef] [PubMed]

27. Luna-Herrera, J.; Martínez-Cabrera, G.; Parra-Maldonado, R.; Enciso-Moreno, J.A.; Torres-López, J.; Quesada-Pascual, F.; Delgadillo-Polanco, R.; Franzblau, S.G. Use of receiver operating characteristic curves to assess the performance of a microdilution assay for determination of drug susceptibility of clinical isolates of Mycobacterium tuberculosis. Eur. J. Clin. Microbiol. Infect. Dis. 2003, 22, 21-27. [PubMed]

28. Nguta, J.M.; Appiah-Opong, R.; Nyarko, A.K.; Yeboah-Manu, D.; Addo, P.G. Current perspectives in drug discovery against tuberculosis from natural products. Int. J. Mycobacteriol. 2015, 4, 165-183. [CrossRef] [PubMed]

Sample Availability: Samples of the all compounds are available from the authors.

(C) 2018 by the authors. Licensee MDPI, Basel, Switzerland. This article is an open access article distributed under the terms and conditions of the Creative Commons Attribution (CC BY) license (http:/ / creativecommons.org/licenses/by/4.0/). 